\title{
KRITERIA DAN INDIKATOR MUTU BIBIT TERHADAP PERSEN HIDUP DAN PERTUMBUHAN TIGA JENIS MERANTI MERAH DI AREAL HPH PT. SARI BUMI KUSUMA, KALIMANTAN TENGAH
}

(Criteria and indicator seedling quality to survival rate and growth of three red meranti species in concession holder PT. Sari Bumi Kusuma, Central Kalimantan)

\author{
$\mathrm{Oleh} / \mathrm{By}$ : \\ R. Mulyana Omon
}

Balai Penelitian Teknologi Perbenihan Samboja

\begin{abstract}
A study on criteria and indicator seedling quality on survival rate and growth of three red meranti species were conducted at PT. Sari Bumi Kusuma concession holder, Central Kalimantan. The purpose of this research to find out information seedlings quality on survival rate and the growth of three species red meranti priority for silin (Indonesian cutting and replanting intensive silviculture system) after a year planted in the field. Treatments consisted of three species (Shorea leprosula Miq., S. parvifolia Dyer and S. johorensis Foxw.) and three seedlings quality class from wildling. Factorial completely randomized block design with four replications was used for this study. Before planting, the seedlings were selected based on it's quality class in nursery. Each treatment consisted of 100 planted seedling with $20 \mathrm{~m} \times 2.5 \mathrm{~m}$ spacing. Therefore, the study observed 3,600 planted seeddlings. The results showed that the species, seedling quality, interaction between species and seedling quality and block did not significant effect on the survival rate. Species and seedling quality gave significant different on height and diameter growth. The height and diameter growth of S. leprosula Miq. was higher than orther species as much as $146.6 \mathrm{~cm}$ and $1.6 \mathrm{~cm}$, respectively. While the height and diameter growth of seedlings quality one was higher than the other seedings quality as much as 142.6 $\mathrm{cm}$ and $1.56 \mathrm{~cm}$. Therefore S. leprosula Miq. from wildling with seedling quality one with height and diameter average of $58.3 \mathrm{~cm}$ and $5.9 \mathrm{~mm}$ respectipely is recommended to used in the program of Indonesian Selective Cutting and Replanting Intensive system.
\end{abstract}

Key Words : Red meranti, seedling quality class, wildling.

\begin{abstract}
ABSTRAK
Penelitian kriteria dan indikator mutu bibit terhadap persen hidup dan pertumbuhan tiga jenis meranti merah telah dilakukan di areal IUPHHK PT. Sari Bumi Kusuma (PT. SBK), Kalimantan Tengah. Tujuan penelitian ini adalah untuk memberikan informasi tentang mutu bibit terhadap persen hidup dan pertumbuhan tiga jenis meranti merah prioritas program silvikultur intensif (silin) setelah satu tahun ditanam di lapangan. Perlakuan terdiri dari tiga jenis meranti merah (Shorea leprosula Miq., $S$. parvifolia Dyer dan S. Johorensis Foxw.) dan tiga mutu bibit asal cabutan. Rancangan percobaan yang digunakan adalah faktorial dalam pola acak lengkap berblok yang diulang sebanyak 4 kali. Sebelum bibit ditanam, dilakukan seleksi bibit berdasarkan klas mutu bibit yang telah dipelihara selama tujuh bulan di persemaian, kemudian ditanam di lapangan. Setiap perlakuan ditanam sebanyak 100 tanaman dengan jarak tanam $20 \mathrm{~m} \times 2,5 \mathrm{~m}$. Jumlah tanaman yang diamati sebanyak 3.600 tanaman. Hasil
\end{abstract}


penelitian menunjukkan bahwa perlakuan jenis, mutu bibit, interaksi antara jenis dan mutu bibit dan blok tidak berpengaruh nyata terhadap persen hidup. Jenis dan mutu bibit memberikan pengaruh yang nyata terhadap pertumbuhan tinggi dan diameter. Pertumbuhan tinggi dan diameter $S$. leprosula lebih tinggi dibandingkan dengan jenis lainnya masing-masing sebesar 146,6 cm and 1,6 cm. Untuk pertumbuhan tinggi dan diameter mutu bibit satu lebih tinggi dibandingkan mutu bibit lainnya, masing-masing sebesar $142,6 \mathrm{~cm}$ and 1,56 cm. Dengan demikian jenis $S$. leprosula dari cabutan dengan mutu bibit satu dengan rata-rata tinggi dan diameter masing-masing sebesar $58,3 \mathrm{~cm}$ dan 5,9 $\mathrm{mm}$ dapat digunakan untuk ditanam dalam program silin (silvikultur intensif) dengan sistem TPTII (Tebang Pilih Tanam Indonesia Intensif).

\section{Kata Kunci : Meranti merah, mutu bibit, cabutan.}

\section{PENDAHULUAN}

Dalam rangka upaya peningkatan produktivitas hutan tanaman meranti lewat kegiatan silvikultur intensif (silin), pemerintah $c q$ Departemen Kehutanan berdasarkan SK Dirjen Bina Produksi Kehutanan Nomor: SK.221-BPH/VI-BPHA/2005 telah menetapkan 6 IUPHHK (Izin Usaha Pemanfaatan Hasil Hutan Kayu) model untuk melaksanakan berbagai kegiatan terkait dengan program SILIN atau yang lebih dikenal dengan Sistem TPTII (Tebang Pilih Tanam Indonesia Intensif). Enam IUPHHK tersebut adalah PT. Sari Bumi Kusuma (PT SBK), PT. Erna Juliawati (PT. ERNA), PT. Sarmento Parakanca Timber (PT. SARPATIM), PT. Balikpapan Forestry Industry (PT BFI), PT. Suka Jaya Makmur (PT. SJM), dan PT. IKANI yang kesemuanya ada di Kalimantan.

Dipterocarpaceae merupakan salah satu famili yang mempunyai banyak jenis dan kayunya bernilai ekonomi tinggi. Bahkan beberapa jenis mempunyai pertumbuhan yang cukup cepat seperti Shorea leprosula Miq., S. parvifolia Dyer., S. johorensis Foxw., S. smithiana Sym. dan S. platycaldos Sloot.ex Foxw. Suparna dan Purnomo (2004) melaporkan bahwa pertumbuhan jenis tersebut pada umur 4,5 tahun rata-rata riap diameternya dapat mencapai $1,8-1,9 \mathrm{~cm} /$ th di kawasan IUPHHK PT. Sari Bumi Kusuma, Kalimantan Tengah.

Jenis tersebut diprioritaskan untuk ditanam dalam program SILIN (Silvikultur Intensif). Oleh karena itu untuk menunjang program tersebut diperlukan bibit bermutu agar tegakan yang dihasilkan juga bermutu. Untuk mendapatkan bibit yang bermutu diperlukan penilaian mutu bibit dalam rangka upaya standarisasi.

Standarisasi mutu bibit Dipterorapaceae dapat dilakukan melalui pembuatan kriteria mutu bibit yang terukur dan bersifat kuantitatif. Penilaian dapat didasarkan pada fenotip bibit karena mudah diukur dan dapat dianggap sebagai gambaran genetik. Zobelt dan Talbert (1984) menjelaskan bahwa ciri atau sifat yang sering ditampilkan setiap individu tidak lepas dari pengaruh lingkungan dan 
genetik. Apabila kualitas fenotip baik maka kita mengetahui bahwa individu tersebut memiliki potensi genetik untuk tumbuh baik (Schmidt, 2000).

Hendromono dan Effendi (2002) melaporkan ciri-ciri mutu bibit Dipterocarpaceae yang baik adalah (1) mempunyai batang tunggal yang tegak dan bebas dari penyimpangan; (2) batangnya kokoh dan mempunyai akar besar; (3) sistem perakaran padat dan banyak, rambut/serabut akar ujungnya berwarna putih; (4) akarnya bebas dari bentuk-bentuk penyimpangan; (5) terdapat mikoriza pada akar; (6) pertumbuhan tunas dan akar seimbang; (7) daun-daunya sehat berwarna hijau gelap dan (8) terbiasa tumbuh dengan kurang air dalam waktu pendek.

Perlu diketahui bahwa Standar Nasional Indonesia (SNI) untuk jenis meranti (SNI 01-5005.11999) yang telah dibuat tidak didasarkan pengujian di lapangan, tetapi hanya di persemaian. Oleh karena itu untuk penelitian kriteria dan indikator mutu bibit ini mengacu pada SNI, telah lakukan uji coba di lapangan sampai dengan umur satu tahun di areal IUPHHK PT. Sari Bumi Kusuma dengan mengevaluasi persen hidup dan pertumbuhan tinggi dan diameter.

Tujuan dari penelitian ini adalah untuk memberikan informasi mengenai kriteria mutu dan indikator mutu bibit dan pertumbuhan tiga jenis meranti prioritas program silin yang mengacu pada kelas mutu bibit SNI jenis meranti untuk diuji di lapangan. Ketiga jenis tersebut adalah $S$. leprosula, $S$. parvifolia dan $S$. johorensi. Hasil dari penelitian ini diharapkan dapat menjadi bahan untuk melengkapi penyusunan SNI untuk beberapa jenis meranti.

\section{METODOLOGI PENELITIAN}

\section{A. Lokasi dan Waktu Penelitian}

Lokasi uji coba mutu bibit ketiga jenis meranti telah dilakukan di areal IUPHHK PT. Sari Bumi Kusuma di Blok Seruyan yang secara geografis terletak antara $00^{\circ} 36^{\prime}-01^{\circ} 10^{\prime}$ Lintang Selatan dan $111^{\circ} 39^{`}-112^{\circ} 25^{`}$ Bujur Timur. Secara administratif termasuk dalam Kecamatan Seruyan Hulu Kabupaten Seruyan, Propinsi Kalimantan Timur.

Jenis tanah blok Seruyan didominasi oleh jenis Kombisol Distrik. Podsolik Kandik dan Oksisol Hapik dengan formasi geologinya didominasi oleh lonalit, granodiorit, granit, sedikit diorit dan garbo (PT. SBK, 2007). Topografi umumnya bergelombang sampai berbukit dan terletak pada ketinggian $100 \mathrm{~m}-1.552 \mathrm{~m}$ dpl.

Berdasarkan klasifikasi iklim Schmidt dan Ferguson (1951) termasuk tipe iklim A dengan ratarata curah hujan $282,33 \mathrm{~mm} /$ bulan dan hari hujan 12,08 hari.

Waktu penelitian dilakukan pada pertengahan bulan September 2007 untuk seleksi bibit di persemaian berdasarkan kriteria dan indikator mutu bibit. Selanjutnya dilakukan penanaman, kemudian diamati terhadap persen hidup dan pertumbuhan tinggi dan diameter setelah satu tahun bibit ditanam di lapangan, yaitu pada pertengahan bulan September 2008. 


\section{B. Bahan dan Alat}

Bahan yang digunakan adalah tiga jenis bibit meranti merah yaitu S. leprosula, , S.parvifolia dan $S$. johorensis yang berasal dari cabutan dan telah dipelihara di persemaian selama tujuh bulan. Kantong plastik yang digunakan berukuran $15 \mathrm{~cm} \times 20 \mathrm{~cm}$ dengan media tumbuh bibit adalah topsoil. Peralatan lapangan yang digunakan dalam penelitian seperti meteran, kaliper, mistar dan kamera.

Sebelum bibit ditanam di lapangan bibit di persemaian diklasifikasikan berdasarkan kriteria dan indikator tiga kelas mutu bibit yang mengacu pada kelas mutu bibit meranti yang telah tersedia (SNI 01-5006.1-1999) ditambah dengan satu kelas mutu bibit di bawahnya, yaitu yang tinggi $<35 \mathrm{~cm}$ dan diameter $<4,0 \mathrm{~mm}$, seperti disajikan pada Tabel 1 .

Tabel 1. Kriteria dan indikator mutu bibit (Criteria and indicator of seedling quality)

\begin{tabular}{|l|l|c|c|c|}
\hline No & $\begin{array}{l}\text { Penilaian kreteria dan indikator mutu } \\
\text { bibit(value criteria and indicator } \\
\text { seedling quality) }\end{array}$ & $\begin{array}{l}\text { Mutu bibit - satu } \\
\text { (seedling quality - I) }\end{array}$ & $\begin{array}{l}\text { Mutu bibit - } \\
\text { dua (seedling } \\
\text { quality -2) }\end{array}$ & $\begin{array}{l}\text { Mutu bibit - tiga } \\
\text { (seedling quality } \\
-3)\end{array}$ \\
\hline 1. & $\begin{array}{l}\text { Kekompakkan media (media } \\
\text { compaction) }\end{array}$ & - & - & - \\
\hline 2. & Tinggi (height) & $50-65 \mathrm{~cm}$ & $35-49 \mathrm{~cm}$ & $35<\mathrm{cm}$ \\
\hline 3. & Diameter (diameter) & $5,0-8,0 \mathrm{~mm}$ & $4,0-4,9 \mathrm{~mm}$ & $4,0<\mathrm{mm}$ \\
\hline 4. & $\begin{array}{l}\text { Nilai kekokohan bibit (strength value } \\
\text { of seedling) }\end{array}$ & - & - & - \\
\hline 5. & Pucuk/akar (top root ratio) & - & - & - \\
\hline
\end{tabular}

\section{Rancangan Percobaan}

Penelitian menggunakan faktorial dengan pola Rancangan Acak Kelompok (RAK) dengan perlakuan jenis dan kelas mutu bibit yaitu :

Faktor A adalah mutu bibit :

$\mathrm{A} 1=$ S. leprosula

A2 $=S$. parvifolia

$\mathrm{A} 3=S$. johorensis

Faktor B adalah jenis :

B1 = Kelas mutu bibit-1

B2 = Kelas mutu bibit-2

B3 = Kelas mutu bibit-3

Masing-masing perlakukan terdiri dari 4 ulangan dan masing-masing ulangan bibit yang ditanam sebanyak 100 bibit dan tiga jenis meranti (Shorea leprosula, S. parvifolia dan S. johorensis). Jumlah bibit yang ditanam adalah $100 \times 4 \times 3 \times 3=3.600$ bibit. Dengan jarak tanam $2,5 \mathrm{~m} \times 20 \mathrm{~m}$ maka luas areal penanaman adalah $2,5 \times 20 \times 3.600=180.000 \mathrm{~m}^{2}$ atau seluas 18 ha atau enam ha untuk setiap jenisnya. 


\section{Penanaman di Lapangan}

Untuk penanaman di lapangan pertama-tama dilakukan persiapan lahan sesuai pedoman teknis sistem TPTI Intensif, bibit ditanam dengan sistem jalur dengan jarak tanam 2,5 m x $20 \mathrm{~m}$. Jarak antar jalur $17 \mathrm{~m}$ dan jarak antar bibit di dalam jalur 2,5 m dengan lebar jalur $3 \mathrm{~m}$ vertikal. Semua tumbuhan yang ada di dalam jalur penanaman dibersihkan sepanjang $250 \mathrm{~m}$.

Kegiatan penyiapan lahan meliputi pembersihan jalur, pemasangan ajir ,pembuatan lubang tanam dan penanaman. Pembersihan jalur dilakukan dengan membersihkan jalur penanaman dari tumbuhan dengan lebar $3 \mathrm{~m}$ vertikal, baik secara manual maupun mekanis. Lubang tanam dibuat ditengah jalur dengan ukuran lubang $40 \mathrm{~cm}$ x $40 \mathrm{~cm}$ dan kedalaman $30 \mathrm{~cm}$. Sebelum dilakukan penanaman, lubang tanam diisi dengan topsoil yang diambil di sekitar jalur antara. Setelah satu tahun ditanam, pengukuran tinggi dilakukan alat ukur meteran yang dibuat dari galah yang telah diberi tanda meteran. Pengukuran tinggi dilakukan mulai dari pangkal pohon sampai ujung pohon (pucuk) dan diameter diukur $10 \mathrm{~cm}$ dari permukaan tanah dengan alat ukur kaliper. Untuk pemeliharaan disesuaikan dengan petunjuk teknis TPTII tetapi tidak dilakukan penyulaman.

\section{E. Analisis Data}

Data yang dianalisis adalah persen hidup bibit, pertambahan (riap) tinggi dan diameter setelah satu tahun ditanam di lapangan. Apabila hasil Uji F hitung menunjukkan adanya pengaruh perlakuan maka dilakukan uji lanjutan dengan uji beda nyata Tukey (Haeruman, 1975). Untuk data penunjang kualitas mutu bibit dilakukan penilaian terhadap nilai kekokohan, top root ratio dan kekompakan media pada waktu penanaman

Untuk penilaian kekokohan bibit dan top root ratio pada setiap kelas mutu bibit diambil masingmasing 10 bibit sebagai sampel untuk masing-masing jenis. Kekokohan bibit dihitung sebagai rasio antara tinggi bibit $(\mathrm{cm})$ dengan diameter $(\mathrm{mm})$ (Jayusman, 2005) dan nilai top root ratio ditentukan berdasarkan pengukuran yang dihitung sebagai rasio antara tinggi bibit $(\mathrm{cm})$ dengan panjang akar $(\mathrm{cm})$. Penilaian ini dilakukan di persemaian dan setelah bibit diseleksi baru ditanam di lapangan.

\section{HASIL DAN PEMBAHASAN}

\section{Nilai kekokohan, Top Root Ratio dan Kekompakan Media}

Penentuan mutu (kualitas) bibit selain pertumbuhan tinggi dan diameter juga indikator lainnya,yaitu nilai kekokohan, top root ratio dan kekompakan media pada saat ditanam. Indikator ini sangat penting untuk menunjang kualitas bibit sebelum ditanam di lapangan. Hasil pengukuran dan penilaian rata-rata dari kriteria dan indikator tersebut disajikan pada Tabel 2. 
Tabel 2 menyajikan rata-rata hasil pengkuran dan penilaian sebelum bibit ditanam berdasarkan jenis dan mutu bibit yang digunakan sebagai penunjang dalam penentuan kualitas mutu bibit.

Tabel 2 (Table 2). Rata-rata hasil pengukuran dan pengamatan kriteria dan indikator mutu tiga bibit jenis meranti merah sebelum di lakukan penanaman di lapangan (Average result of meansuration and observation of criteria and indicator of seedling quality three red meranti species before planting in the field).

\begin{tabular}{|c|c|c|c|c|c|c|}
\hline \multirow[t]{2}{*}{ No } & \multirow[t]{2}{*}{ Jenis (Species) } & \multirow[t]{2}{*}{$\begin{array}{l}\text { Media tumbuh } \\
\text { (Planted media) }\end{array}$} & \multirow[t]{2}{*}{$\begin{array}{l}\text { Kreteria penilaian } \\
\text { (Valuation criteria) }\end{array}$} & \multicolumn{3}{|c|}{$\begin{array}{l}\text { Kualitas mutu bibit (Criteria } \\
\text { seedling quality) }\end{array}$} \\
\hline & & & & $\mathrm{B}_{1}$ & $\mathrm{~B}_{2}$ & $\mathrm{~B}_{3}$ \\
\hline \multirow[t]{5}{*}{1} & S. leprosula & Top soil & $\begin{array}{l}\text { Kekompakan media } \\
\text { (media compaction) }\end{array}$ & utuh & utuh & utuh \\
\hline & & & Tinggi (height) & $58,3 \mathrm{~cm}$ & $42,3 \mathrm{~cm}$ & $31,4 \mathrm{~cm}$ \\
\hline & & & Diameter (diameter) & $5,9 \mathrm{~mm}$ & $4,3 \mathrm{~mm}$ & $3,5 \mathrm{~mm}$ \\
\hline & & & $\begin{array}{l}\text { Nilai kekokohan } \\
\text { (Strength value) }\end{array}$ & 9,88 & 9,85 & 10,83 \\
\hline & & & $\begin{array}{l}\text { Pucuk/akar (root top } \\
\text { ratio) }\end{array}$ & 2,19 & 2,59 & 2,01 \\
\hline \multirow[t]{5}{*}{2} & S.parvifolia & & $\begin{array}{l}\text { Kekompakan media } \\
\text { (media compaction) }\end{array}$ & utuh & utuh & utuh \\
\hline & & & Tinggi (height) & $56,1 \mathrm{~cm}$ & $42,3 \mathrm{~cm}$ & 31,4 \\
\hline & & & Diameter (diameter) & $5,5 \mathrm{~mm}$ & $4,3 \mathrm{~mm}$ & $3,4 \mathrm{~mm}$ \\
\hline & & & $\begin{array}{l}\text { Nilai kekokohan } \\
\text { (Strength value) }\end{array}$ & 10,2 & & \\
\hline & & & $\begin{array}{l}\text { Pucuk/akar (root top } \\
\text { ratio) }\end{array}$ & 2,37 & 2,59 & 2,23 \\
\hline \multirow[t]{5}{*}{3} & S. johorensis & Top soil & $\begin{array}{l}\text { Kekompakan media } \\
\text { (media compaction) }\end{array}$ & utuh & utuh & utuh \\
\hline & & & Tinggi (height) & $55,5 \mathrm{~cm}$ & $38,1 \mathrm{~cm}$ & $24,3 \mathrm{~cm}$ \\
\hline & & & Diameter (diameter) & $5,6 \mathrm{~mm}$ & $4,5 \mathrm{~mm}$ & $3,6 \mathrm{~mm}$ \\
\hline & & & $\begin{array}{l}\text { Nilai kekokohan } \\
\text { (Strength value) }\end{array}$ & 9,9 & 8,4 & 6,8 \\
\hline & & & $\begin{array}{l}\text { Pucuk/akar (root top } \\
\text { ratio) }\end{array}$ & 2,43 & 2,4 & 1,6 \\
\hline
\end{tabular}

\section{Persentase Hidup}

Dari hasil analisis keragaman bahwa perlakuan jenis, mutu bibit, interaksi antara jenis dan mutu bibit dan blok tidak menunjukkan perbedaan yang nyata terhadap persen hidup ke tiga jenis meranti merah, seperti disajikan pada Tabel 3

Pada Tabel 3 disajikan bahwa persen hidup untuk ketiga kelas mutu bibit dan ketiga jenis meranti merah cukup bervariasi, akan tetapi secara analisis keragaman tidak menunjukkan perbedaan yang nyata. Jika dilihat persen hidup dari setiap jenis dan kelas mutu bibit cukup baik yaitu di atas $75 \%$. Daryadi dan Harjono (1972) melaporkan dengan besar persentase hidup tersebut selama satu tahun ditanam dikategorikan cukup baik. Ditambah lagi pada saat penanaman selama satu tahun tersebut tidak dilakukan penyulaman, tetapi hanya pemeliharaan sesuai dengan pedoman teknis TPTII. Maksud tidak dilakukannya penyulaman setelah tiga bulan ditanam adalah untuk melihat kemampuan hidup dari masing-masing jenis dan kelas mutu bibit selama satu tahun ditanam di lapangan. 
Tabel 3 (Table 3). Rata-rata persen hidup berdasarkan jenis dan mutu bibit setelah satu tahun ditanam di lapangan (Average survival rate based on species and seedling quality after one year planted in the field).

\begin{tabular}{|c|c|c|c|c|c|}
\hline \multirow{2}{*}{ No } & \multirow{2}{*}{ Jenis (species) } & \multicolumn{3}{|c|}{ Mutu bibit (seedling quality) \% } & Rata-rata (average) \\
\cline { 3 - 5 } & & $\mathrm{B}_{1}$ & $\mathrm{~B}_{2}$ & $\mathrm{~B}_{3}$ & $\%$ \\
\hline & $\mathrm{A}_{1}=$ S. leprosula & 77,8 & 76,3 & 81,0 & 78,4 \\
\hline & $\mathrm{A}_{2}=$ S. parvifolia & 78,5 & 75,8 & 76,7 & 77,0 \\
\hline & $\mathrm{A}_{3}=$ S. johorensis & 77,3 & 74,6 & 74,1 & 75,3 \\
\hline
\end{tabular}

\section{Riap Tinggi dan Diameter}

Dari hasil analisis keragaman jenis dan mutu bibit telah menunjukkan pengaruh yang nyata terhadap pertambahan tinggi (riap tinggi), sedangkan interaksi antara jenis dan mutu bibit dan blok tidak menunjukkan perbedaan yang nyata terhadap pertumbuhan tinggi bibit setelah satu tahun ditanam di lapangan.

Untuk mengetahui jenis mutu bibit mana yang berpengaruh terhadap riap tinggi perlu dilakukan uji lanjutan dengan uji Tukey. Berdasarkan hasil uji beda nyata Tukey dengan nilai $\mathrm{W}_{(0,05)}$ sebesar 25,5 seperti terlihat pada Gambar 1.
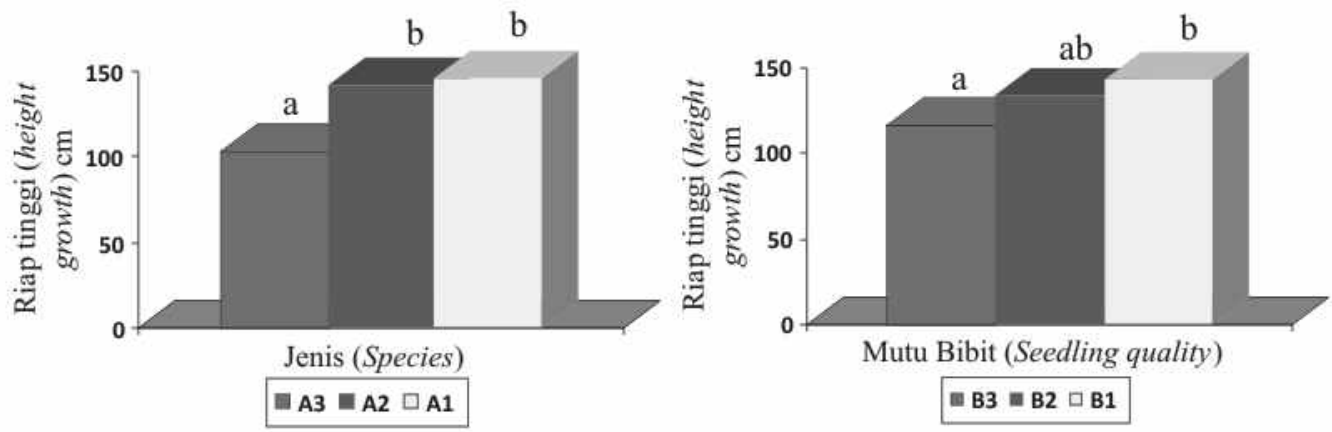

Gambar (Figure 1). Rata-rata hasil uji beda nyata Tukey terhadap riap tinggi tiga jenis meranti merah setelah satu tahun ditanam di lapangan (Average results of significant different test of Tukey on height growth of three red meranti species after one year planted in the field)

Keterangan (Remarks): Nilai rata-rata yang diikuti oleh hurup berbeda menunjukkan perbedaan yang nyata pada tingkat $5 \%$ berdasarkan uji beda nyata Tukey (Mean values followed by different letters are significanly different at $5 \%$ level based on Tukey significant different test)

Gambar 1 menunjukkan bahwa riap tinggi jenis $S$. leprosula lebih tinggi dan berbeda nyata dibandingkan dengan riap $S$. johorensis, yaitu sebesar 30\%, sedangkan dengan jenis $S$. parvifolia tidak menunjukkan perbedaan yang nyata terhadap riap tinggi, yaitu masing-masing sebesar 146,6 $\mathrm{cm}, 142,6 \mathrm{~cm}$ dan $103,6 \mathrm{~cm}$.

Untuk rata-rata tinggi mutu bibit satu (Tabel 1) dengan kelas tinggi antara $(50 \mathrm{~cm}-65 \mathrm{~cm})$ menunjukkan bahwa riap tinggi lebih tinggi dan berbeda nyata dibandingkan rata-rata mutu bibit tiga 
(Tabel 1) dengan kelas tinggi $<35 \mathrm{~cm}$, sedangkan rata-rata mutu bibit dua (Tabel 1) dengan kelas tinggi antara $(35 \mathrm{~cm}-49 \mathrm{~cm})$ tidak menunjukkan perbedaan nyata terhadap riap tinggi, yaitu masingmasing sebesar $142,6 \mathrm{~cm}, 133,6 \mathrm{~cm}$ dan $116,4 \mathrm{~cm}$.

Hasil analisis keragaman menunjukkan bahwa riap diameter dan tinggi telah memberikan pengaruh yang sama, yaitu jenis dan mutu bibit memberikan pengaruh yang nyata terhadap riap diameter. Interaksi antara jenis dan mutu bibit dan blok tidak menunjukkan perbedaan yang nyata terhadap riap diameter setelah satu tahun ditanam. Tetapi untuk mengetahui sejauhmana perbedaan antara jenis dan mutu bibit tersebut terhadap riap diameter telah dilakukan uji lanjutan dengan uji Tukey. Dari hasil uji Tukey diperoleh nilai $\mathrm{W}_{(0,05)}$ sebesar 0,24 seperti disajikan pada Gambar 2 .
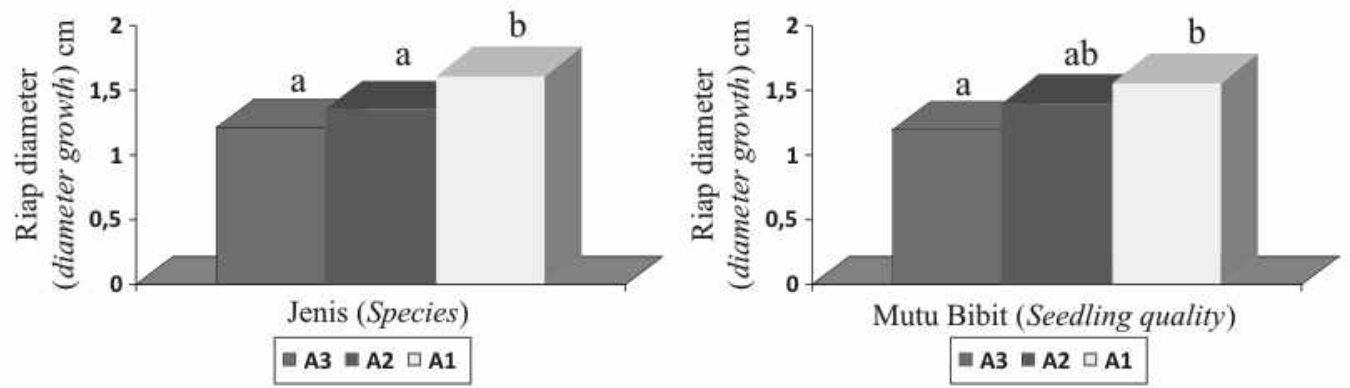

Gambar (Figure )2. Rata-rata hasil uji beda nyata Tukey terhadap riap diameter ketiga jenis meranti merah setelah satu tahun di tanam di lapangan (Average results of significant different test of Tukey on diameter growth of three red meranti species after one year planted in the field)

\begin{abstract}
Keterangan (Remarks): Nilai rata-rata yang diikuti oleh hurup berbeda menunjukkan perbedaan yang nyata pada tingkat $5 \%$ berdasarkan uji beda nyata Tukey (Mean values followed by different letters are significanly different at $5 \%$ level based on Tukey significant different test)
\end{abstract}

Gambar 2 memperlihatkan bahwa riap diameter jenis $S$. leprosula lebih tinggi dan berbeda nyata dibandingkan dengan jenis lainnya, yaitu masing-masing sebesar 1,6 mm, 1,35 mm dan 1,21 mm. Untuk rata-rata diameter mutu bibit satu (Tabel 1) dengan kelas diameter antara (5,0 mm - 8,0 mm) riap diameter lebih tinggi dibandingkan dengan rata-rata mutu bibit tiga (Tabel 1) dengan diameter $<4,0 \mathrm{~mm}$, kecuali dengan rata-rata mutu bibit dua (Tabel 1)) dengan kelas diameter antara (4,0 mm $4,9 \mathrm{~mm}$ ) tidak menunjukkan perbedaan yang nyata terhadap riap diameter setelah satu tahun ditanam di lapangan.

Tinggi dan diameter merupakan karakteristik pertumbuhan yang paling mudah diukur dan sering dijadikan standar dalam penentuan kualitas bibit. Hasil analisis keragaman menunjukkan bahwa riap tinggi dan diameter jenis $S$. leprosula lebih tinggi dibandingkan dengan jenis lainnya, yaitu masingmasing sebesar $149,2 \mathrm{~cm}$ dan $1,6 \mathrm{~cm}$.

Angka pertumbuhan tinggi dan diameter setelah ditanam di lapangan ternyata akan semakin besar apabila ukuran tinggi dan diameter bibit yang ditanam semakin besar atau terdapat korelasi yang 
tinggi antara tinggi dan diameter bibit di persemain dengan pertumbuhan tinggi dan diameter di lapangan. Akan tetapi Zobel dan Talbert (1984) menyatakan bahwa pada umumnya pertumbuhan tinggi pohon lebih kuat dipengaruhi susunan genetik dibandingkan dengan diameter. Soerianegara (1970) berpendapat bahwa sifat tinggi termasuk salah satu sifat adetif yang kuat dipengaruhi oleh susunan genetik. Oleh karena itu perbedaaan riap tinggi dan diameter antara jenis tersebut disebabkan oleh faktor genetik disamping lingkungan. Jayusman (2006) melaporkan bahwa penampilan karakter pertumbuhan tinggi dan diameter dipengaruhi oleh empat faktor yaitu: (1) unsur hara dalam tanah, (2) ketersediaan air, (3) cahaya dan (4) genetik.

Pertumbuhan diameter batang merupakan sifat yang sangat penting, karena riap diameter berpengaruh terhadap perkembangan tanaman. Oleh karena itu perlu diupayakan pemeliharaan jenis yang mempunyai pertumbuhan diameter yang cepat (fast growing). Seperti diketahui bahwa jenisjenis yang ditanam dalam kegiatan program silin telah dipilih dari jenis-jenis meranti yang mempunyai riap diameter cukup cepat. Jenis tersebut antara lain Shorea leprosula, S. parvifolia, $S$. johorensis, S. smithiana dan S. platycaldos (Soekotjo, 2007).

Untuk memperoleh pertumbuhan dan persen hidup yang tinggi diperlukan mutu bibit yang baik sebelum ditanam di lapangan. Berdasarkan hasil analisis keragaman mutu bibit satu dengan kelas tinggi antara $(50 \mathrm{~cm}-65 \mathrm{~cm})$ dan kelas diameter antara $(5,0 \mathrm{~mm}-8,0 \mathrm{~mm})$ telah memberikan riap tinggi dan diameter lebih tinggi dibandingkan dengan kelas mutu bibit yang lainnya. Selain itu kelas mutu bibit berdasarkan kelas tinggi dan diameter ditunjang pula oleh nilai kekokohan bibit dan top root ratio sebelum bibit ditanam. Karakter penunjang ini sering dipakai untuk menilai sifat morfologis bibit di persemaian (Jayusman, 2006). Kekokohan bibit menggambarkan keseimbangan pertumbuhan antara tinggi dan diameter bibit di lapangan. Nilai kekokohan yang tinggi akan menunjukkan kemampuan hidup yang rendah karena tidak seimbangnya perbandingan tinggi bibit dengan diameternya. Nilai kekokohan bibit di persemaian berkisar antara 6,3-10,8 dikelompokkan baik (SNI 015006.1-1999). Dari hasil perhitungan rata-rata kekokohan bibit meranti merah jenis S. leprosula dari bibit yang berasal dari cabutan yang dipelihara selama tujuh bulan di persemaian dengan nilai kekokohan sebesar 9,88 termasuk dalam kategori yang baik. Untuk nilai penunjang lainnya, yaitu top root ratio, makin kecil top ratio akan menunjukkan pertumbuhan kurang baik. Nilai top ratio yang baik berkisar antar 2 -3 termasuk dalam kelompok baik. Berdasarkan hasil penilaian top ratio dari penelitian rata-rata sebesar 2,19, sehingga termasuk dikategorikan baik. Selain itu tidak kalah pentingnya media yang digunakan untuk pertumbuhan bibit di persemaian. Berdasarkan hasil pengamatan di lapangan media tumbuh dengan topsoil cukup baik, yaitu pada waktu penanaman bibit ke lubang tanam tidak terjadi kerusakan artinya antara tanah dan akar melekat (utuh). Akan tetapi yang menjadi kendala apabila media tumbuh bibit mengandalkan topsoil dikhawatirkan akan terjadi kerusakan tanah hutan. Oleh karena itu saat ini di IUPHHK seperti PT. SBK dan PT. SARPATIM telah menggunakan kompos buatan yang terbuat dari kayu yang telah lapuk kemudian diracik menjadi kompos. Ada juga yang dibuat dari vegetasi tumbuhan bawah yang diracik dengan alat pecincang rumput 
kemudian ditambah M4 untuk dijadikan kompos. Kompos tersebut dicampur dengan topsoil dengan perbandingan 1: $3(\mathrm{v} / \mathrm{v})$.

Berdasarkan dari uraian di atas bahwa standar mutu bibit yang telah tersedia untuk jenis meranti (SNI 01-5006.1-1999), yaitu kelas mutu satu dan dua dapat digunakan sebagai bahan acuan untuk penanaman bibit operasional di lapangan dalam program silin, khususnya dari jenis S.leprosula dan S.parvifolia seperti disajikan pada Gambar 3.

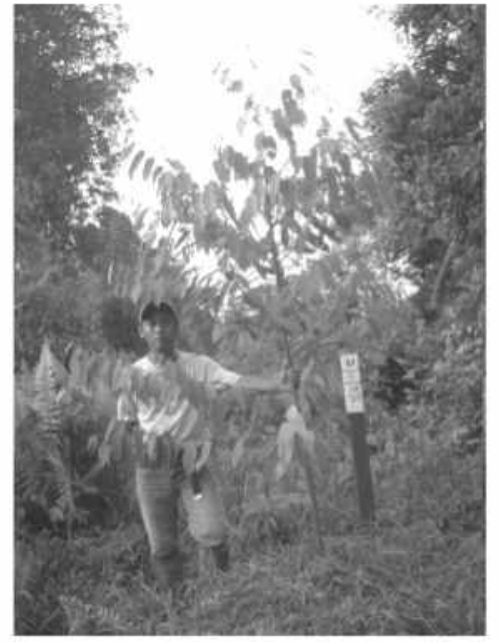

Mutu Bibit 1 (S. leprosula)

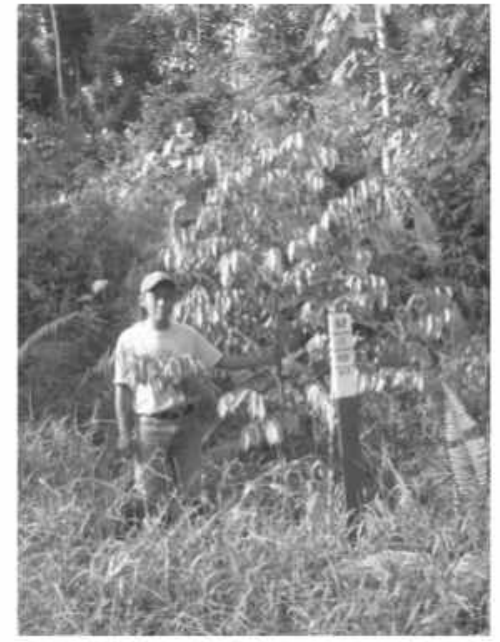

Mutu Bibit 1 (S. parvifolia)

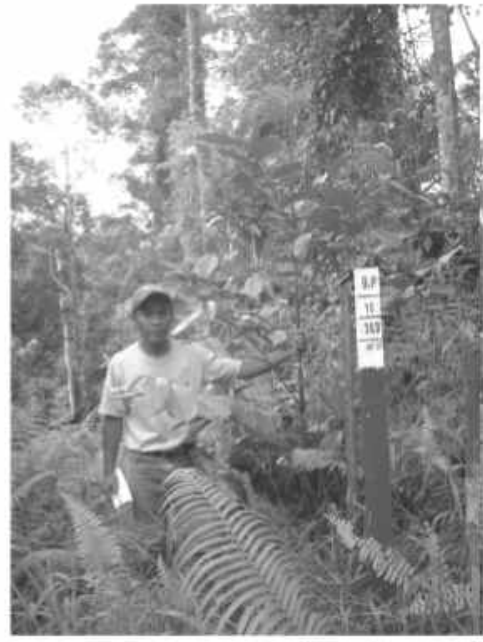

Mutu Bibit 1 ( $S$. johorensis)

Gambar 3 (Figure 1). Mutu bibit satu dari jenis S. leprosula, S. parvifolia dan S. johorensis setelah satu tahun di lapangan ( Seedling quality one of S. leprosula, S. parvifolia and $S$. johorensis after one year in the field)

\section{KESIMPULAN DAN SARAN}

\section{a. Kesimpulan}

1. Riap tinggi dan diameter jenis $S$. leprosula lebih tinggi dibandingkan dengan jenis S. parvifolia dan $S$. johorensis setelah satu tahun ditanam di lapangan yaitu masing-masing sebesar 149,2 cm dan 1,6 $\mathrm{cm}$ dengan persen hidup sebesar $77,8 \%$.

2. Kelas mutu bibit satu dengan rata-rata tinggi $58,3 \mathrm{~cm}$ atau dengan kelas tinggi antara $(50 \mathrm{~cm}-65$ $\mathrm{cm})$ dan rata-rata diameter 5,9 $\mathrm{mm}$ dengan kelas diameter antara $(5,0 \mathrm{~mm}-8,00 \mathrm{~mm})$ memberikan riap tinggi dan diameter lebih tinggi dibandingkan dengan kelas mutu lainnya, yaitu masingmasing sebesar $142,6 \mathrm{~cm}$ dan $1,6 \mathrm{~cm}$.

3. Nilai kekokohan bibit, top root ratio dan kekompakan media sangat penting sebagai penunjang untuk penentuan kualitas (mutu) bibit untuk ditanam di lapangan, yang masing-masing 9,88 dan 2,19 serta utuh. 


\section{b. Saran-Saran}

Perlu dilakukan uji coba bibit jenis Dipterokarpa lainnya dengan bibit yang berasal dari cabutan atau benih.

\section{DAFTAR PUSTAKA}

Daryadi, L dan Harjono (1972). Sendi-sendi silvikultur. Lembaga Penelitian Kehutanan, Bogor.

Direktorat Jendral Bina Produksi Kehutanan, 2005. Pedoman Tebang Pilih Tanam Indonesia Intensif/TPTII (Silvikultur Intensif). Direktorat Bina Pengembangan Hutan Alam, Direktorat Jenderal Bina Produksi Kehutanan, Departemaen Kehutanan

Haeruman, H. 1975. Prosedur analisa rancangan percobaan. Bagian pertama. Bagian Perencanaan Hutan. Departemen Manajemen Hutan, Fakultas Kehutanan, IPB, Bogor. 78 h.

Hendromono dan R. Effendi. 2002. Produksi bibit Dipterocarpaceae melalui biji dan cabutan. Dalam Yasman, I dan Hernawan eds. Manual Persemaian Dipterocarpaceae. Departemen Kehutanan, Tropenbos International, SFMP-GTZ, Asosiasi Pengusaha Hutan Indonesia (APHI), IFSPDANIDA, Alterra-Green World Research, PT. INHUTANI I. Jakarta.

Jayusman. 2005. Evaluasi keragaman genetik bibit surian di persemaian. Wana Benih Vol. 7 No. 1.

Pusat Penelitian dan Pengembangan Hutan Tanaman. Yogyakarta.

Schmidt dan Ferguson, 1951. Rainfall types based on dry and wet period ratios for Indonesia with Western New Guinea. Verhandelingen No. 42. Jawatan Meteorologi dan Geofisika, Jakarta.

Schmidt, L. 2000. Pedoman penanganan benih tanaman hutan tropis dan sub tropis. Terjemahan Direktorat Jenderal Rehabilitasi Lahan dan Perhutanan Sosial.

Soerianegara, I.1970. Pemuliaan Hutan (Forest Tree Improvement). Lembaga Penelitian Hutan. Direktorat Jendral Kehutanan, Bogor.

Soekotjo. 2007. Pengalaman Dari Uji Jenis Dipterokarpa Umur 4,5 Tahun Di PT SA BUMI KUSUMA Kalteng. Prosiding Seminar Pengembangan Hutan Tanaman Dipterokarpa dan Ekspose TPTII/Silin, Balai Besar Penelitian Dipterokarpa, Samarinda Kaltim, tanggal 4-5 September 2007 Di Samarinda

Suparna, N dan Purnomo., 2004. Pengalaman Membangun Hutan Tanaman Meranti Di PT. Sari Bumi Kusuma Kalimantan Tengah. Makalah disampaikan pada Seminar Nasional dalam rangka 70 tahun Prof. Dr Ir Soekotjo dengan tema Visi Silvikultur Indonesia menyongsong Kehutanan 2045 tanggal 4-5 Maret 2004, di Yogyakarta

PT. SBK. 2007. TPTI Intensif Di PT Sari Bumi Kusuma. Prosiding Seminar Pengembangan Hutan Tanaman Dipterokarpa dan Ekspose TPTII/Silin, Balai Besar Penelitian Dipterokarpa, Samarinda Kaltim. 
JURNAL PENELITIAN DIPTEROKARPA

Vol. 4 No. 1, Juni 2010

Zobel, B and J.Talbert. 1984. Applied Forest Tree Improvement. John Wiley and Sons.Inc. New York. 